\title{
РЕАБІЛТТАЦІЙНІ ЗАХОДИ ДЛЯ ЖІНОК У ПЕРІОД ПОСТМЕНОПАУЗИ ПРИ ДИСФУНКЦІЇ М’ЯЗІВ ТАЗОВОГО ДНА І ПОРУШЕННЯХ СЕЧОВИПУСКАННЯ
}

\author{
Л. М. Волкова, Г. О. Стельмах, Т. Г. Бакалюк \\ Тернопільський національний медичний університет \\ імені І. Я. Горбачевського МОз Украӥни
}

У статті проведено аналіз основних факторів ризику, що спричиняють розвиток і прогресування неспроможності м’язів тазового дна. Представлено патогенетичні концепції розвитку нетримання сечі, які пов’язані 3 дисфункцією м’язів тазового дна, та реабілітаційні підходи для корекції цього симптомокомплексу.

\section{REHABILITATION MEASURES FOR WOMEN IN THE POSTMENOPOUSE PERIOD IN DYSFUNCTION OF THE PELVIC FLOOR MUSCULES AND URINAL DISORDERS}

\section{M. Volkova, H. O. Stelmakh, T. H. Bakaliuk \\ I. Horbachevsky Ternopil National Medical University}

The article analyzes the main risk factors that contribute to the development and progression of pelvic floor muscle failure. Pathogenetic concepts of the development of urinary incontinence related to pelvic floor dysfunction and rehabilitation approaches to correct this symptom complex are presented.

Вступ. Нетримання сечі (НC) у жінок $є$ актуальною медичною, соціально-економічною та психологічною проблемою. Розлади сечовиділення у жінок спричиняють важкі фізичні та моральні страждання, зумовлені глибокою психічною травмою, сексуальним конфліктом, розвитком неврозу та неврастенії, втратою працездатності [1, 2].

Частота поширення НС у жінок становить 15-30 \% залежно від використовуваних методів визначення діагностики [2, 3]. За даними статистики, в Україні близько 5 млн осіб відзначають симптоми мимовільного виділення сечі. Результати останніх епідеміологічних досліджень відображають такі дані: у віці 25-34 роки частота НС складає 9 \%, збільшуючись після 55 років до 36 \% [6]. У великому багатоцентровому проспективному американському дослідженні SWAN показано, що у більшості жінок НС починає проявлятися одночасно із настанням менопаузи [8].

Значна поширеність НС і небажання жінок миритися з цією проблемою дуже очевидні $[3,11]$. На сьогодні важлива не тільки правильна розробка чіткого діагностичного і лікувального алгоритму ведення жінок

(с Л. М. Волкова, Г. О. Стельмах, Т. Г. Бакалюк, 2020 із даною патологією, а й визначення реабілітаційних заходів та профілактики.

У зв'язку зі збільшенням тривалості життя (7782 роки, за даними Всесвітньої організації охорони здоров'я) та підвищенням вимог до якості життя в будь-якому віковому періоді діагностика і лікування даних пацієнток стають особливо актуальними [1].

Оскільки нетримання сечі $\epsilon$ поліетіологічним багатофакторним захворюванням, з'ясування впливу дисфункції м'язів тазового дна на цей симптомокомплекс та визначення реабілітаційних підходів стало метою нашого дослідження.

Основна частина. Враховуючи актуальність проблеми НС у жінок в постменопаузальний період, провели огляд літератури про вплив на порушення сечовиділення функції м'язів тазового дна.

Тазове дно - це збірне поняття, що включає всі анатомічні структури, які утворюють дно черевної порожнини. Органи, розташовані в тазу, - сечовий міхур, уретра, матка, пряма кишка і задній прохід безпосередньо прилягають до тазового дна. У тазовому дні умовно виділяють 4 основних шари. Крім кількох шарів м'язів у стабілізації стану тазового дна величез- 
не значення мають зв'язковий і сухожильний апарати, що утворюють топографічно кілька рівнів підтримки для органів малого таза [4].

Під терміном «дисфункція тазового дна» розуміють комплекс порушень функції зв'язкового апарату і м'язів тазового дна, що підтримують органи малого таза в нормальному положенні та забезпечують утримання сечі й калу. У численних вітчизняних та іноземних дослідженнях проводять спроби розглянути і систематизувати загальні фактори ризику розвитку всіх проявів дисфункції тазового дна [13]. Епідеміологічні дослідження вказують на збільшення частоти дисфункції тазового дна ужінок похилого віку, але процес старіння не $\epsilon$ окремим фактором ризику розвитку цього тяжкого симптомокомплексу [5, 8, 9]. Збільшення частоти захворювання насамперед зумовлено зростанням супутніх захворювань, які в сукупності визначають фактори ризику. Безсумнівно, вікові зміни зв'язкового і м'язового апарату тазового дна спричиняють розвиток його дисфункції та появу симптомів пролапсу внутрішніх статевих органів, нетримання сечі й калу [13].

Міцність і еластичність структур тазового дна при нормальному стані достатні для того, щоб підтримувати органи таза навіть при підвищенні внутрішньочеревного тиску в межах фізіологічної норми. Порушення функції двох структурно взаємопов'язаних тканин - м'язової та сполучної - призводить до ослаблення або до зміни функції м'язів тазового дна [7].

Нормальне сечовипускання забезпечує сечовий міхур, сечовивідний канал, їх м'язовий апарат, а також фасції, м'язи і зв'язки, які утримують сечовий міхур і формують тазове дно [4]. Порушення анатомічного взаєморозміщення тазових органів (сечового міхура, сечовивідного каналу з іншими органами тазового дна) або функції їх нервових рецепторів викликають порушення сечовипускання у жінок. Ці стани виникають після ускладнених пологів, операцій на органах тазового дна, при великому навантаженні, ожирінні, хронічних запальних процесах $[5,8]$.

Збільшення віку призводить до старіння організму і прогресуючого зниження функціональних можливостей, знижується м'язова маса, погіршуються властивості сполучної тканини, зменшується вироблення колагену, що в сукупності спричиняє порушення м'язово-скелетних структур всього організму, погіршення функції тазових органів $[1,2,5]$.

Зі збільшенням маси тіла зростає тиск на м'язи тазового дна, який чиниться органами черевної по- рожнини і малого таза. Зниження індексу маси тіла може приводити в деяких випадках до зменшення симптомів нетримання сечі $[2,3]$. У ході тривалого семирічного проспективного дослідження, проведеного в Австралії (Melbourne Women's Midwife Health Project), показано, що менопауза не впливає на розвиток НС у жінок [5]. В іншому рандомізованому дослідженні, яке включало 1253 жінки, були зроблені такі ж висновки [8]. Очевидно, нетримання сечі пов'язано не з переходом жінки в менопаузу, а з загальними віковими змінами.

Фізична активність є однією зі складових життєдіяльності людини, бере участь у багатьох фізіологічних процесах організму, їі відсутність, як і високі навантаження на організм, можуть спричиняти розвиток різних патологічних розладів. Доведено, що помірна фізична активність сприяє підтримці скоротливої здатності м'язів, прискореному оновленню складової частини сполучної тканини - колагену $[8,10]$.

У 1948 р. вправи Кегеля були вперше описані Арнольдом Кегелем для зміцнення м'язів тазового дна. Перинеометр, який також називають вагінальним манометром, розроблений для фіксації сили стиснення м'язів тазового дна і може використовуватися для того, щоб направляти учасників правильно виконувати вправи. Дослідження доктора Кегеля показало, що вправи можуть допомогти запобігти нетриманню сечі при цистоцеле, ректоцеле та сечовому стресі [12]. Ештон-Міллер та ін. вказували, що уретральні сфінктери та підтримувальні системи у жінок можуть запобігти нетриманню сечі та пролапсу статевих органів. Підтримувальні системи складаються з м'язів тазового дна, стінки піхви, тазової фасції, тазової арки та ендопельвікальної фасції [7].

Розроблені спеціальні вправи для тренування м'язів тазового дна дозволяють ефективно зміцнювати ці м'язи, запобігаючи розвитку функціональних і дисфункціональних розладів тазових органів. Чим раніше виявлена дисфункція тазових органів і розпочата реабілітація для відновлення функціональних розладів, тим більш значних результатів можливо досягти. Ефективність проведення тренування м'язів тазового дна може сягати 78-85 \% [9, 10]. Навантаження повинно бути дозованим, оскільки надмірне фізичне навантаження, підвищуючи внутрішньочеревний тиск, видавлює органи черевної порожнини через слабкі місця тазової діафрагми.

Помірні регулярні фізичні навантаження, в першу чергу аеробні, стимулюють процеси гідроксилювання 
і детоксикацію естрогенів, зменшують венозний і лімфатичний застій в органах малого таза, підвищують кисневий обмін, нормалізують вуглеводний і жировий обмін, знижують рівень інсуліну. Особливе значення серед фізичних вправ мають вправи Кегеля, які забезпечують збільшення еластичності тканин і відновлення сили скорочень м'язів малого таза $[11,12,14]$.

Проведене O. Celiker et al. дослідження показало, що тренування м'язів тазового дна ефективно знижує симптоми стресового і змішаного нетримання сечі та збільшує силу м'язів тазового дна [9]. У багатоцентровому рандомізованому контрольованому дослідженні, проведеному S. Hagen et al., доведено, що жінки, які отримували індивідуальні програми тренувань м'язів тазового дна, повідомили про зниження симптомів пролапсу через 12 місяців на відміну від контрольної групи, що істотно поліпшило їм якість життя [10]. У той же час, за даними досліджень S. Yang et al., показано, що вправи Кегеля в поєднанні з електростимуляцією для відновлення м'язів тазового дна показали добрі результати: зменшилася частота нетримання сечі, підвищилася сила м'язів тазового дна [14].

\section{СПИСОК ЛІТЕРАТУРИ}

1. Медицина климактерия / под ред. В. П. Сметник. Ярославль : ООО «Издательство Литера», 2006. - 848 с.

2. Гаджиева 3. К. Недержание мочи у женщин / З. К. Гаджиева, М. А. Газимиев, Г. Р. Касян // Урология. - 2016. № 2. - С. 20-36.

3. Глыбочко П. В. Интегративная урология / П. В. Глыбочко, Ю. Г. Аляев. - М. : Медфорум, 2014. - 185 с.

4. Горовий В. І. Клінічна анатомія сечостатевих органів : навч. посіб. / В. І. Горовий, В. О. Шапринський, Б. Ф. Мазарчук. - Вінниця : ТОВ «Нілан-лТД», 2016. - 640 с.

5. Кулавский В. А. Влияние неблагоприятных факторов образа жизни на развитие несостоятельности мышц тазового дна и пролапса тазовых органов / В. А. Кулавский, А. М. Зиганшин // Российский вестник акушера-гинеколога. - 2009. - Т. 9, № 4. - С. 36-41.

6. Яцина О. І. Якість життя жінок в її взаємозв'язку із поширеністю розладів сечовипускання в Україні / О. І. Яцина // Урологія. - 2018. - № 4 (87). - С. 17-23.

7. Ashton-Miller J. A. Functional anatomy of the female pelvic floor / J. A. Ashton-Miller, J. O. DeLancey // Ann. N. Y. Acad. Sci. - 2007. - Vol. 1101. - P. 266-296. [PubMed]

8. Urinary incontinence in older women: Who is at risk? / J. S. Brown, D. G. Seeley, J. Fong [et al.] // Obstet. Gynecol. 1996. - Vol. 87. - P. 715-721.

9. Does pelvic floor muscle training abolish symptoms of urinary incontinence? A randomized controlled
Незважаючи на виражені інволютивні процеси в репродуктивній системі у жінок, що супроводжуються явним або латентним нетриманням сечі, тренування м'язів тазового дна за допомогою методів фізичної реабілітації $\epsilon$ ефективною технікою управління захворюванням.

Висновки. 1. У виникненні нетримання сечі в жінок у період постменопаузи значне місце займає дисфункція м'язів тазового дна. Адекватна діагностика та врахування впливу цього фактора підвищать ефективність реабілітаційних заходів.

2. Ефективність тренування мускулатури тазового дна підтверджена великою кількістю незалежних наукових досліджень. На сьогодні вже навіть не обговорюють обґрунтування застосування методів фізичної реабілітації, а мова йде про вибір найефективнішого підходу до реабілітації.

3. Проблема дисфункції тазового дна і розвитку порушень сечовипускання є єдиним цілим і вимагає продовження вдосконалення реабілітаційних стратегій.

trial / O. Celiker, A. M. Ergenoglu, A. O. Yeniel [et al.] // Clin. Rehabil. - 2015. - Vol. 29 (6). - P. 52537. DOI: 10.1177/0269215514546768. Epub 2014 Aug 20.

10. Individualised pelvic floor muscle training in women with pelvic organ prolapse (POPPY): a multicenter randomized controlled trial. POPPY Trial Collaborators / S. Hagen, D. Stark, C. Glazener [et al.] // Lancet. - 2014. - Vol. 383 (9919). P. 796806.

11. EAU Guidelines on Urinary Incontinence / Joachim W. Thüroff, Paul Abrams, Karl-Erik Andersson [et al.] // European Urology. - 2011. - Vol. 59, Issue 3. - P. 387-400.

12. Kegel A. H. Progressive resistance exercise in the functional restoration of the perineal muscles / A. H. Kegel // Am. J. Obstet. Gynecol. - 1948. Vol. 56 (2). P. 238-248. [PubMed]

13. Wein A. J. Association between joint hypermobility and pelvic organ prolapse in women: a systematic review and meta-analysis / A. J. Wein // J. Urology. - 2017. - Vol. 198 (5). P. 988-989.

14. The effect of rehabilitation exercises combined with direct vagina low voltage low frequency electric stimulation on pelvic nerve electrophysiology and tissue function in primiparous women: A randomised controlled trial / S. Yang, W. Sang, J. Feng [et al.] // J. Clin. Nurs. - 2017. DOI: 10.1111/ jocn.13790. 